\title{
Monoclonal Antibody ICR62
}

National Cancer Institute

\section{Source}

National Cancer Institute. Monoclonal Antibody ICR62. NCI Thesaurus. Code C2720.

A rat monoclonal antibody that inhibits Epidermal Growth Factor Receptor (EGFR),

targeting tumor cells expressing the wild-type EGFR and EGFRvIII. ( $\mathrm{NCl})$ 